JURNAL RESPIRASI

$J R$

Vol. 1 No. 3 September 2015

\title{
Obstructive Sleep Apneu (OSA), Obesitas Hypoventilation Syndrome (OHS) dan Gagal Napas
}

Mokhammad Mukhlis, Arief Bakhtiar

Departemen Pulmonologi dan Ilmu Kedokteran Fakultas Kedokteran Universitas Airlangga/RSUD Dr. Soetomo

\begin{abstract}
Background: Obstructive sleep apnea (OSA) is a state of the occurrence of upper airway obstruction periodically during sleep that causes breathing to stop intermittently, either complete (apnea) or partial (hipopnea). Obesity hypoventilation syndrome (OHS) is generally defined as a combination of obesity (BMI $\geq 30 \mathrm{~kg} / \mathrm{mc}$ ) with arterial hypercapnia while awake $(\mathrm{PaCO} 2>45 \mathrm{mmHg})$ in the absence of other causes of hypoventilation. Purpose: In order for the pulomonologis can understand the pathogenesis and pathophysiology of OSA and its complications. Literature review: Several studies have been expressed about the link between OSA, OHS with respiratory failure disease. Pathophysiology of OSA, OHS in respiratory failure were difficult to detect, can cause respiratory failure disease management becomes less effective. Conclusion: A good understanding can help with the diagnosis and management of the appropriate conduct to prevent complications of respiratory failure associated with OSA.
\end{abstract}

Key words: obstructive sleep apnea, obesity hypoventilation syndrome, respiratory failure

Correspondence: Mokhammad Mukhlis, Departemen Pulmonologi dan Ilmu Kedokteran Respirasi, Fakultas Kedokteran Universitas Airlangga/RSUD Dr. Soetomo. Jl. Mayjen. Prof. Dr. Moestopo 6-8 Surabaya 60286. E-mail: mokhammad_mukhlis@ yahoo.com

\section{PENDAHULUAN}

Berdasarkan perhitungan lebih dari satu juta orang di dunia memiliki berat badan yang berlebih atau dikenal dengan istilah obesitas dengan body mass index (BMI) $25 \mathrm{~kg} / \mathrm{m}^{2}$ atau lebih. ${ }^{1}$ Obesitas merupakan penyebab morbiditas, seperti yang terjadi pada 2000 penduduk Amerika Serikat diperkirakan 400.000 kematian disebabkan karena obesitas. ${ }^{2}$ Obesitas terutama abdominal obesity merupakan faktor risiko signifikan untuk penyakit-penyakit kardiovaskuler, diabetes tipe 2, rheumatoid arthritis dan kanker. ${ }^{3}$

Hubungan antara obesitas dan penyakit respirasi kronik mulai mengalami peningkatan dan mulai dikenali. ${ }^{4}$ Organisasi Kesehatan Dunia (WHO) memprediksikan sekitar $10 \%$ dari populasi global akan mengalami obesitas pada tahun $2015 .^{5}$

Sejumlah pasien dengan penyakit respirasi kronik seperti penyakit paru obstruktif kronik (PPOK), asma, obstructive sleep apnea, ditemukan semakin meningkat. Para ahli sering menemui tantangan permasalahan obesitas ditemukan bersamaan dengan penyakit respirasi kronik. Pada kondisi lain, obesitas dapat dijadikan sebagai penyebab terkait dengan kelainan respirasi, biasanya dikenal dengan Obstructive Sleep Apnea (OSA) dan Obesity Hipoventilation Syndrome (OHS). Obesitas juga umumnya dapat ditemukan pada asma dan PPOK, meskipun hubungan alamiah keduanya tidak dapat dijelaskan dengan benar. ${ }^{4}$

Selama beberapa dekade terakhir, pemahaman kita tentang mekanisme penyebab gangguan pernapasan saat tidur terus ditingkatkan dan banyak penelitian berfokus pada mekanisme kontrol ventilasi dan patensi jalan napas atas saat tidur. Ketidakstabilan pola pernapasan dapat terjadi seiring dengan terjadinya resitensi jalan napas atas, peningkatan collapsibility saluran napas atas, dan perburukan mekanisme kontrol refleks lokal, sehingga ini semua menimbulkan Obstructive Apnea. Interaksi antara Obstructive Sleep Apnea (OSA), dan beberapa kategori klinis yang berbeda, seperti PPOK, gagal jantung kronis, gangguan neuromuskuler dan obesitas, dapat menyebabkan gangguan yang lebih kompleks, dan menimbulkan komplikasi berbagai jalur. $^{6}$

Menurut International Classification of Functioning, OHS adalah kondisi kronik yang berhubungan dengan 
respirasi, metabolisme, hormonal, dan gangguan kardiovaskuler. Hal ini menyebabkan penurunan kemampuan melakukan aktivitas kehidupan sehari-hari, kurangnya partisipasi sosial dan berisiko tinggi dirawat di rumah sakit dan kematian. ${ }^{7}$

Periode apnea adalah terjadinya henti napas selama 10 detik atau lebih. Periode hipopnea adalah terjadinya keadaan reduksi aliran udara sebanyak lebih-kurang $30 \%$ selama 10 detik yang berhubungan dengan penurunan saturasi oksigen darah sebesar 4\%. Apnea terjadi karena kolapsnya saluran napas atas secara total, sedangkan hipopnea kolapsnya sebagian, namun jika terjadi secara terus-menerus dapat menyebabkan apnea. ${ }^{21}$

OSA dan PPOK keduanya merupakan gangguan umum, dan sama pentingnya, karena obesitas mulai menjadi epidemi di negara-negara Barat dan demikian juga dengan perilaku merokok selama beberapa dekade akhir-akhir ini. Pasien yang secara bersamaan memiliki kedua gangguan di satu sisi dengan kelainan gangguan aliran inspirasi (OSA) dan di sisi lain dengan gangguan aliran ekspirasi (PPOK). Kedua gangguan respirasi yang terjadi bersamaan ini akan berbahaya di saat tidur dibandingkan dengan hanya satu kelainan saja. ${ }^{5}$

Di Amerika serikat, sepertiga dari populasi dewasa didapatkan obesitas, dan prevalensi obesitas ekstrim (BMI $>40 \mathrm{~kg} / \mathrm{m}^{2}$ ) terus mengalami peningkatan. Sejak tahun 1986 hingga 2005 prevalensi $\mathrm{BMI}>40 \mathrm{~kg} / \mathrm{m}^{2}$ mengalami peningkaan hingga 5 kali lipat, memberi pengaruh 1 dari 200 orang dewasa hingga 1 dari 33 orang dewasa. Hal yang serupa, dimana prevalensi BMI > $50 \mathrm{~kg} / \mathrm{m}^{2}$ mengalami peningkatan 10 kali lipat, memberi pengaruh 1 untuk setiap 2000 orang dewasa hingga 1 untuk setiap 230 orang dewasa. Epidemi obesitas tidak hanya memberikan pengaruh pada orang dewasa di Amerika Serikat, tetapi secara global dapat mempengaruhi pada anak-anak dan remaja, sehingga sepertinya epidemi global obesitas pada prevalensi OHS juga akan terus mengalami peningkatan. Sejumlah penelitian telah melaporkan prevalensi OHS sekitar 10-20\% pada pasien obesitas dengan OSA. Prevalensi OHS paling

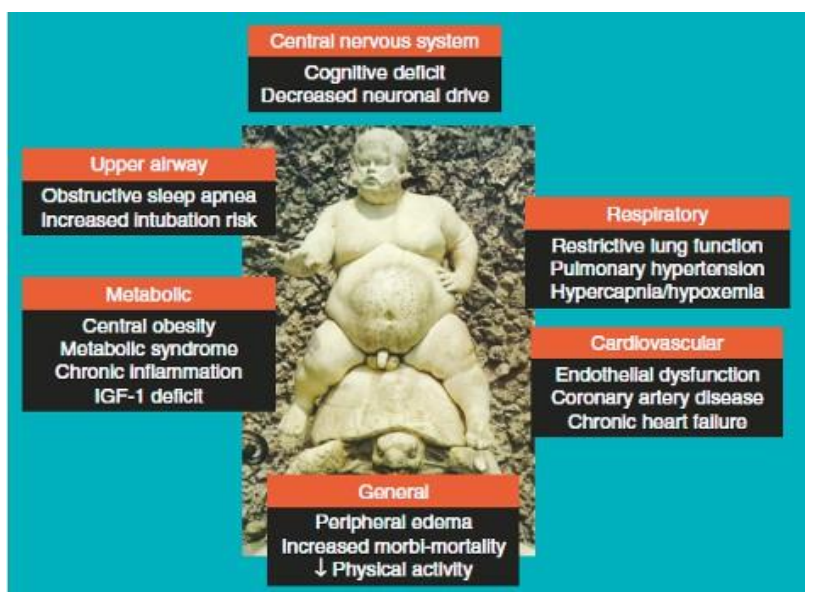

Gambar 1. Konsekuensi sentral dan perifer dikarenakan obesitas $^{8}$ tinggi ditemukan pada subgrup pasien OSA dengan obesitas ekstrim. Dari sebuah metaanalisis 4250 pasien dengan obesitas dan OSA yang tidak menderita PPOK, dilaporkan p19\% dengan prevalensi hiperkapnia. Prevalensi OHS pada pasien dewasa dengan BMI $35 \mathrm{~kg} / \mathrm{m}^{2}$ dilaporkan sekitar $13 \%$. Meskipun prevalensi OHS cenderung meningkat pada pria, akan tetapi pria umumnya tidak jelas dengan OSA atau tidak. Kenyataanya, dari 3 penelitian menunjukkan proporsi OHS yang paling tinggi ditemukan pada wanita. Sama halnya bahwa tidak terdapat predominan ras dan etnis tertentu. Namun dikarenakan tingginya prevalensi obesitas ekstrim pada orang Afrika-Amerika dibanding ras lain, prevalensi OHS dapat menjadi paling tinggi pada orang Afrika Amerika. Karena perbedaan sefalometrik, seperti penyempitan pada tulang oropharing dan displacement inferior pada tulang hioid, OHS berhubungan dengan OSA yang terjadi pada BMI yang rendah pada orang Asia, dibandingkan dengan ras kulit putih. ${ }^{9}$

Tinjauan Kepustakaan ini bertujuan untuk menjelaskan OSA terutama tipe OHS yang menyebabkan terjadinya gangguan pada respirasi sehingga menimbulkan suatu kondisi gagal napas.

\section{Pengaruh Obesitas terhadap Fungsi Respirasi}

Pada klasifikasi berat badan, BMI, indeks berat badan terhadap tinggi badan $(\mathrm{kg} / \mathrm{m} 2)$, umumnya diakui sebagai indikator kesehatan yang paling berguna risiko di kalangan orang-orang yang memiliki kelebihan berat badan atau dengan berat badan yang rendah. ${ }^{10} \mathrm{Hal}$ ini juga diketahui bahwa BMI sendiri tidak memberikan informasi tentang distribusi lemak dalam tubuh. Risiko terhadap kesehatan terkait obesitas, termasuk pengaruhnya terhadap fungsi respirasi, hubungan ini tidak hanya dengan seberapa besar obesitas yang terjadi tetapi juga adanya lemak yang tertimbun di daerah abdominal. Ukuran perut, lingkar pinggang sangat berhubungan dengan jaringan lemak viseral, dan dengan demikian dapat digunakan pada kombinasi dengan BMI sehingga pada kelanjutannya dapat menilai risiko penyakit kardiovaskuler yang berkaitan dengan obesitas. ${ }^{10}$

Akumulasi jaringan lemak dapat mengganggu fungsi ventilasi pada orang dewasa dan anak-anak. ${ }^{14}$ Peningkatan BMI biasanya berhubungan dengan penurunan volume ekspirasi paksa dalam satu detik (FEV1), kapasitas vital paksa (FVC), kapasitas total paru, Kapasitas residu fungsional dan volume cadangan ekspirasi. Restriksi rongga torak terkait dengan obesitas biasanya ringan dan dikaitkan dengan efek mekanik lemak pada diafragma dan dinding dada, ekskursi diafragma terhalang dan compliance rongga dada menurun. Secara klinis terjadi pola restriksi (kapasitas total paru $<85 \%$ prediksi) biasanya ditemukan pada obesitas besar, pada rasio berat terhadap tinggi badan adalah $0,9-1,0 \mathrm{~kg} / \mathrm{m}$ atau lebih besar. Namun, kelainan restriksi masih mungkin ditemukan pada obesitas dengan rasio berat badan terhadap tinggi kurang dari $0,9 \mathrm{~kg} / \mathrm{cm}$. ini biasanya terjadi dengan adanya penumpukan lemak sentral, yang ditandai dengan rasio pinggang-pinggul 0,95 atau 
lebih. Ketika obesitas yang terjadi kurang dari ukuran masif, kelainan restriksi tidak berhubungan dengan penumpukan lemak sampai penyebab lain dari restriksi diketahui, seperti penyakit paru interstitial atau penyakit neuromuscular, telah dieksklusi. ${ }^{11}$

Penurunan rasio FEV1/FVC (< 70\%) pada pemeriksaan spirometri, menandakan sudah terjadi obstruksi aliran udara, bukan merupakan gambaran dari gangguan respirasi terkait dengan obesitas, meskipun ada beberapa studi yang mengatakan adanya keterlibatan saluran napas kecil berkaitan dengan obesitas. Kapasitas difusi ditemukan meningkat pada obesitas, tapi ini bukanlah temuan yang sering didapatkan. Kekuatan otot pernapasan dapat mengalami kelemahan pada obesitas, dimana terdapat penurunan tekanan inspirasi maksimal pada subyek yang obesitas dibandingkan dengan subyek kontrol terhadap berat badan tubuh normal. Kelemahan otot pernafasan pada obesitas telah dikaitkan dengan kelemahan otot, akibatnya menurunnya compliance dinding dada atau volume paru berkurang atau dapat terjadi keduanya. Tidak mengherankan, kapasitas latihan sering terganggu pada pasien obesitas. Meskipun latihan kardiorespirasi dinilai dengan kemampuan konsumsi oksigen maksimal adalah umumnya megalami penurunan pada pasien obesitas, status fungsional selama latihan seperti berjalan mengalami penurunan karena meningkatnya metabolik membawa tubuh dengan berat badan ekstra. ${ }^{12}$

Ada hubungan yang jelas antara dispneu dan obesitas. Obesitas meningkatkan kerja pernapasan (work of breathing) karena penurunan compliance dinding dada dan penurunan kekuatan otot pernapasan ini menimbulkan ketidakseimbangan antara kebutuhan terhadap kerja otot pernapasan dan kapasitas menghasilkan tegangan, sehingga menimbulkan sebuah persepsi peningkatan usaha untuk bernapas. Selanjutnya, dispneu pada pasien obesitas bisa menyingkap tabir kondisi lain yang terkait, seperti pernafasan dan penyakit jantung. Diantara penyakitpenyakit tersebut, asma patut diperhatikan secara khusus. Pasien dengan obesitas sering mengalami dispneu dan mengi dan karena itu sering diberikan terapi untuk asma tanpa konfirmasi diagnostik dengan melakukan pemeriksaan fungsi paru. Diagnosis yang akurat penting ditegakkan karena dispneu terkait dengan mekanisme atau penyakit lain memerlukan strategi terapi yang berbeda. ${ }^{13}$

\section{Obstructive Sleep Apnea (OSA)}

Apnea obstruktif adalah hilangnya udara pernapasan selama 10 detik atau lebih disertai usaha aktif untuk bernapas yang ditandai oleh pergerakan tipikal dinding dada dan dinding perut. Hypopnea obstruktif adalah berkurangnya $50 \%$ atau lebih udara pernafasan selama paling sedikit 10 detik terkait dengan penurunan saturasi oksigen $4 \%$ atau lebih disertai dengan pergerakan tipikal dinding dada dan dinding perut. Severitas OSA digambarkan dengan rata-rata jumlah apnea dan hypopnea per jam selama tidur yakni Apnea-Hypopnea Index (AHI). Obstructive Sleep Apnea ringan adalah $\mathrm{AHI} \leq 5$, OSA sedang adalah $\mathrm{AHI}=6-9$, OSA berat adalah $\mathrm{AHI} \geq 30 .{ }^{24}$
Obstructive Sleep Apnea (OSA) merupakan kelainan respiratorik kronis yang ditandai oleh episode apnea dan hypopnea akibat obstruksi saluran napas saat tidur. Obstructive sleep apnea (OSA) adalah kelainan yang merupakan bagian dari sleep disorder breathing syndrome yang kompleks. Sebenarnya gejala OSA sering terjadi, namun sulit untuk dideteksi. OSA adalah keadaan terjadinya obstruksi jalan napas atas secara periodik selama tidur yang menyebabkan napas berhenti secara intermiten, baik komplit (apnea) atau parsial (hipopnea). Diagnosis OSA ditegakkan jika jumlah frekuensi penurunan aliran udara yang berhubungan dengan kolapsnya saluran napas atau apnea-hipopnea index (AHI), lebih dari 5 kali dalam 1 jam tidur. Hal tersebut dapat menyebabkan terjadinya periode arousal (terbangun atau gelisah dalam tidurnya) dan tidur kembali. AHI diperoleh dengan melakukan pemeriksaan polisomnografi. Berdasarkan penelitian dilaporkan $24 \%$ pria dan $9 \%$ wanita dewasa mempunyai angka kejadian atau AHI lebih dari 5 /jam. Dilaporkan bahwa $4 \%$ pria, $2 \%$ wanita dan $1-3 \%$ pada anak mempunyai gejala OSA, termasuk adanya gejala daytime hypersomnolence yang diakibatkan oleh kejadian apnea-hipopnea. Empat penelitian prevalensi berskala besar menyatakan satu dari lima orang dewasa kulit putih yang memiliki rata-rata indeks massa tubuh (IMT) $25-28 \mathrm{~kg} / \mathrm{m}^{2}$ memiliki AHI $\geq 5$ '/jam. Dilaporkan satu dari 15 pasien OSA memiliki AHI 15 atau lebih. Wanita pasca-menopause memiliki risiko OSA lebih tinggi yang dihubungkan dengan faktor hormonal dan orang usia lanjut memiliki prevalensi OSA lebih tinggi dari dewasa muda. Gejala daytime hypersomnolence lebih jarang muncul pada orang usia lanjut. ${ }^{14}$

Prevalens yang sebenarnya pasien OSA dalam populasi tidak diketahui, karena banyak yang belum menjalani pemeriksaan polisomnografi dan tetap tidak terdiagnosis. Suatu studi berbasis populasi memperkirakan 1 dari 5 orang dewasa muda dengan Indeks Massa Tubuh (IMT) $25-28 \mathrm{~kg} / \mathrm{m}^{2}$ di negara Barat memiliki OSA dan 1 dari 20 orang tersebut memiliki gejala OSA. Pasien dengan OSA umumnya memiliki berat badan berlebih atau obesitas dan gangguan metabolik, seperti intoleransi glukosa, resistensi insulin dan dislipidemia yang merupakan faktor risiko utama penyakit kardiovaskular. OSA terdapat pada lebih dari $40 \%$ individu dengan IMT $\geq 30 \mathrm{~kg} / \mathrm{m}^{2}$ atau individu dengan sindroma metabolik. ${ }^{15}$

Istilah primary snoring (mendengkur primer) digunakan untuk menggambarkan anak dengan kebiasaan mendengkur yang tidak berkaitan dengan obstruktif apnea, hipoksia atau hipoventilasi. Guilleminault dkk mendefinisikan sleep apnea sebagai episode apnea sebanyak 30 kali atau lebih dalam 8 jam, lamanya paling sedikit 10 detik dan terjadi baik selama fase tidur rapid eye movement (REM) dan non rapid eye movement (NREM). Terdapat istilah apnea index (AI) dan hypopnea index (HI) yaitu frekuensi apnea atau hipopnea per jam. Apnea atau hypopnea index dapat digunakan sebagai indikator berat ringannya OSA. ${ }^{16}$

Beberapa faktor predisposisi OSA antara lain obesitas, ukuran lingkar leher, umur, jenis kelamin, hormon dan 
kelainan anatomi saluran napas. Obesitas dilaporkan sebagai faktor utama yang dapat meningkatkan risiko terjadinya OSA. Dari kepustakaan dinyatakan bahwa penderita OSA setidaknya memiliki indeks massa tubuh (IMT) satu tingkat di atas normal (IMT normal $\left.20-25 \mathrm{~kg} / \mathrm{m}^{2}\right)$. Penelitian lain melaporkan bahwa ukuran lingkar leher (> 42,5 $\mathrm{cm}$ ) berhubungan dengan peningkatan AHI. ${ }^{17}$

Obstructive sleep apnea juga dapat dipicu dengan kebiasaan merokok dan minum alkohol. Rokok mempengaruhi OSA melalui mekanisme gangguan tidur yang tidak stabil karena kadar nikotin yang turun pada malam hari. Asap rokok memicu inflamasi dan kerusakan mekanik saraf pada saluran napas atas serta meningkatkan risiko kolaps otot-otot faring selama tidur. Kebiasaan minum alkohol terbukti pula memicu peningkatan resistensi nasal dan faring secara akut. Konsumsi alkohol menjelang waktu tidur akan mempengaruhi timbulnya hipopnea dan apnea saat tidur. ${ }^{18}$ Faktor lain yang mungkin berperan dalam OSA adalah ras dan genetik. ${ }^{19}$ Analisis regresi pada penelitian Buxbaum dkk menunjukkan bahwa 35\% dari variasi gejala klinis OSA berkaitan dengan faktor genetik. Ras afrika-amerika lebih rentan terhadap kejadian OSA daripada ras eropa-amerika ${ }^{20}$

Ada tiga faktor yang berperan pada patogenesis OSA: pertama, obstruksi saluran napas daerah faring akibat pendorongan lidah dan palatum ke belakang yang dapat menyebabkan oklusi nasofaring dan orofaring, yang menyebabkan terhentinya aliran udara, meskipun pernapasan masih berlangsung pada saat tidur. Hal ini menyebabkan apnea, asfiksia sampai periode arousal. Faktor kedua adalah ukuran lumen faring yang dibentuk oleh otot dilator faring (m. pterigoid medial, $\mathrm{m}$. tensor veli palatini, m. genioglosus, m. geniohioid dan m. sternohioid) yang berfungsi menjaga keseimbangan tekanan faring pada saat terjadinya tekanan negatif intratorakal akibat kontraksi diafragma. Kelainan fungsi kontrol neuromuskular pada otot dilator faring berperan terhadap kolapsnya saluran napas. Defek kontrol ventilasi di otak menyebabkan kegagalan atau terlambatnya refleks otot dilator faring, saat pasien mengalami periode apnea-hipopnea. ${ }^{21}$

Faktor ketiga adalah kelainan kraniofasial mulai dari hidung sampai hipofaring yang dapat menyebabkan penyempitan pada saluran napas atas. Kelainan daerah ini dapat menghasilkan tahanan yang tinggi. Tahanan ini juga merupakan predisposisi kolapsnya saluran napas atas. Kolaps nasofaring ditemukan pada $81 \%$ dari 64 pasien OSA dan $75 \%$ di antaranya memiliki lebih dari satu penyempitan saluran napas atas.

Kegiatan tidur yang mencakup $1 / 3$ dari kegiatan hidup kita merupakan proses fisiologis yang kompleks dan dinamis. Tidur diklasifikasikan menjadi Rapid Eye Movement (REM) dan Non-Rapid Eye Movement (NREM). Tidur REM yang meliputi $25 \%$ dari waktu tidur ditandai oleh pergerakan bola mata yang cepat pada elektrookulogram, hilangnya tonus otot tubuh dan meningkatnya aktivitas simpatis (meningkatnya denyut jantung dan tekanan darah).
Tidur NREM yang meliputi bagian terbanyak dari waktu tidur (75\%) dibagi menjadi tingkat I, II, III dan IV. Tingkat I dan III meliputi waktu yang singkat dan merupakan waktu tidur transisi. Sebagian besar tidur NREM terdiri dari tingkat II dan IV. Tidur NREM ditandai oleh penurunan denyut jantung, tekanan darah dan aktivitas simpatis lainnya yang bergradasi dari tingkat I sampai dengan aktivitas simpatis terendah pada tingkat IV. Bermacammacam penyakit gangguan tidur dapat mengganggu proses fisiologis tidur normal. OSA adalah penyakit gangguan tidur yang paling sering ditemukan pada pasien dengan penyakit kardiovaskular. $^{22}$

OSA sering tidak terdeteksi karena terjadi saat pasien tidur. Gejala OSA dikelompokkan menjadi gejala malam dan gejala siang hari. Gejala utama OSA adalah daytime hypersomnolence. Gejala ini tidak dapat dinilai secara kuantitatif karena pasien sering sulit membedakan rasa mengantuk dengan kelelahan. Hampir 30\% pria dan $40 \%$ wanita dewasa dengan nilai AHI > 5 /jam mengeluh tidak segar saat bangun. Dilaporkan $25 \%$ pria dan $30 \%$ wanita dewasa mengeluh mengalami rasa mengantuk yang berlebihan di siang hari. Epworth Sleepiness Scale (Ess) dan Standford Sleepiness Scale (SSS) adalah kuisioner yang mudah dan cepat untuk menilai gejala rasa mengantuk. Skala ini tidak berhubungan secara langsung dengan indeks apnea-hipopnea. Penyebab daytime hypersomnolence adalah karena adanya tidur yang terputus-putus, berhubungan dengan responss saraf pusat yang berulang karena adanya gangguan pernapasan saat tidur. Dilaporkan $50 \%$ penderita OSA mempunyai tekanan darah di atas normal, meskipun tidak diketahui apakah hal tersebut merupakan penyebab atau sebagai akibat apnea tidur. Risiko serangan jantung dan stroke juga dilaporkan meningkat pada penderita OSA. ${ }^{21}$

Gejala yang paling sering ditemukan pada pasien dengan OSA selain mendengkur saat tidur adalah excessive daytime sleepiness, yakni sering tertidur saat melakukan kegiatan sehari-hari di siang hari, seperti membaca, berbincang-bincang, makan, atau pun mengendarai mobil. Gejala terkait lainnya adalah lelah saat bangun tidur di pagi hari, episode seperti tercekik atau terengah-engah di malam hari, sakit kepala di pagi hari, mulut kering atau sakit tenggorokan di pagi hari, refluks asam lambung, nokturia sampai dengan gejala yang berat seperti gangguan kognitif dan ingatan. Gejala yang terpenting yang diperlukan dalam mendiagnosis pasien dengan OSA adalah laporan dari teman tidur pasien yang menyaksikan langsung adanya apnea nokturnal. Pemeriksaan fisis pada pasien OSA dapat saja ditemukan normal, tapi biasanya berkaitan dengan kelebihan berat badan atau obesitas. Peningkatan lingkar leher (lebih dari 17 inchi) lebih spesifik daripada IMT dalam memprediksi OSA. Gambaran anatomi lainnya seperti palatum mole yang rendah, orofaring yang sempit, uvula yang besar, mikrognatia dan retrognatia merupakan predisposisi OSA. $^{22}$

Prediksi seorang ahli berdasarkan gejala yang dialami pasien dan pemeriksaan fisis saja hanya memiliki akurasi diagnosis sebesar 50\%, maka dibutuhkan 
beberapa pemeriksaan penunjang untuk membantu dalam mendiagnosis OSA. Epworth Sleepiness Scale adalah suatu kuesioner sederhana yang dapat memberikan informasi seberapa mudah seseorang untuk tertidur, sedangkan Berlin Questionnaire dapat digunakan untuk melakukan stratifikasi risiko OSA, yang terdiri dari IMT, riwayat hipertensi, beberapa pertanyaan mengenai seberapa sering seseorang tertidur di siang hari, severitas dan frekuensi mendengkur dan seberapa sering seseorang tertidur saat mengendarai mobil. ${ }^{18}$

Polisomnografi merupakan pemeriksaan baku emas dalam menegakkan diagnosis OSA. Pada pemeriksaan ini, selama pasien tidur akan dilakukan pengukuran berkesinambungan elektroensefalogram, okulogram, elektromiogram submental dan tibial, elektrokardiogram, aliran udara naso-oral, saturasi oksigen perifer dan pergerakan dinding dada dan dinding perut. Melalui pemeriksaan ini akan didapatkan informasi mengenai efisiensi tidur, posisi tidur, frekuensi dan penyebab pasien terbangun, timbulnya gangguan pernafasan saat tidur, fluktuasi saturasi oksigen dan aritmia jantung spesifik. ${ }^{25}$

\section{Obesitas Hypoventilation Syndrom (OHS)}

Pada beberapa orang gemuk, ketidakseimbangan beban yang berlebihan terhadap kemampuan pernafasan dapat menimbulkan suatu kegagalan pernapasan hiperkapnia pada ketiadaan penyebab lain hipoventilasi. Kondisi ini disebut obesitas Sindrom hipoventilasi (OHS). Sindrom ini termasuk ke dalam golongan Obstructive Sleep Apneu (OSA), dengan nilai AHI > 5/jam, didapatkan 90\% dari mereka dengan OHS selain dari itu ada yang tidak memiliki OSA tetapi mengalami hipoventilasi saat tidur yang didefinisikan sebagai peningkatan $\mathrm{PaCO} 2$ selama tidur setidaknya $10 \mathrm{~mm} \mathrm{Hg}$ lebih tinggi daripada saat terjaga atau terjadinya desaturasi signifikan yang tidak dapat dijelaskan melalui apnoe atau hipopnoea. Namun, bahkan di antara gemuk tidak sehat $\left(\mathrm{BMI}>40 \mathrm{~kg} / \mathrm{m}^{2}\right)$ dengan OSA, kurang dari seperempat dapat menderita OHS. Pengamatan tersebut menunjukkan bahwa meskipun tingkat yang lebih tinggi dari obesitas mempengaruhi untuk OHS, faktor-faktor lain hadir yang telah didalilkan untuk menjelaskan diferensial kerentanan ini. ${ }^{26}$
Pada akhir spektrum sleep disordered breathing, yang dimulai dengan mendengkur sederhana dan berkembang menjadi OSA (akhirnya dalam hubungan dengan PPOK), OHS dapat ditemukan. OHS umumnya didefinisikan sebagai kombinasi antara obesitas (BMI $\geq 30 \mathrm{~kg} / \mathrm{mc}$ ) dengan hiperkapnia arteri saat terjaga $(\mathrm{PaCO} 2>45 \mathrm{mmHg})$ tanpa adanya penyebab hipoventilasi lain. Pasien ditandai dengan beberapa gejala, episode obstruksi, hipoventilasi atau hipoventilasi obstruktif berlangsung terus menerus karena obstruksi jalan napas atas parsial. Tidak diketahui dengan pasti mengapa beberapa pasien obesitas dapat menderita OHS, sementara yang lain tidak, juga tidak dipahami dengan benar etiologi dari OHS, meskipun hampir pasti multifaktorial di alam. Pasien mungkin mengeluh kelelahan atau kantuk siang hari, tetapi banyak tetap asimtomatik dimana dapat tidur tanpa keluhan. Hipoventilasi tidur saja tidak mendefinisikan OHS kecuali hiperkapnia terjadi siang hari juga timbul. Itu adalah hipotesis bahwa pasien obesitas dengan hipoventilasi selama tidur tanpa hiperkapnia terjaga memiliki "prodromal" bentuk OHS dan kemudian akan dapat menimbulkan sebuah kondisi hiperkapnia kronis. Beberapa penulis berpendapat bahwa OHS adalah gangguan campuran "tidak bisa bernapas" (tidak mampu mengatasi hambatan pernapasan akibat gangguan pengaturan fungsi paru, kinerja pernapasan otot, dan/atau efek pembebanan massa obesitas) dan "tidak dapat bernapas" (penurunan gangguan kemampuan ventilasi). Kemampuan Respons terhadap beban abnormal, disfungsi otot ventilasi, peningkatan kerja pernapasan dan produksi $\mathrm{CO} 2$, gangguan pernafasan pusat dan obstruski saluran udara berulang selama tidur, semua ini memungkinkan sebagai komponen patofisiologi dalam konsep ini, tetapi kontribusi yang tepat dari setiap komponen harus sepenuhnya dapat dijelaskan. Respons yang berbeda terhadap CPAP, BPAP dan NIV mungkin merefleksikan sesuatu yang menarik, berat badan dengan mekanisme patofisiologi yang berbeda mungkin bervariasi pada setiap individu dengan OHS. Hal ini dapat dilihat pada beberapa pasien, OSA derajat berat mungkin dapat menjadi kontributor utama dalam patofisiologi terjadinya OHS, dengan mekanik sistem pernapasan hanya memiliki peranan kecil. Pasien ini bisa berhasil diobati dengan CPAP jangka panjang. Dan sebaliknya, pasien

Tabel 2. Batasan definisi Obesity Hipoventilation Syndrome. ${ }^{9}$

\begin{tabular}{|c|c|}
\hline Required Conditions & Description \\
\hline Obesity & $\mathrm{BMI} \geq 30 \mathrm{~kg} / \mathrm{m}^{2}$ \\
\hline hypoventilation & Awake daytime hypercapnia $\left(\mathrm{P}_{\mathrm{a}} \mathrm{co}_{2} \geq 45 \mathrm{~mm} \mathrm{Hg}\right.$ and $\left.\mathrm{P}_{\mathrm{a}} \mathrm{O}_{2}<\mathrm{mm} \mathrm{Hg}\right)$ \\
\hline Sleep-disodered breathing & $\begin{array}{l}\text { Obstructive sleep apnea- hypopnea index } \geq 5 \text { events/h, with or without sleep hypoventilation) pres- } \\
\text { ent in } 90 \% \text { of cases. }\end{array}$ \\
\hline \multirow{6}{*}{$\begin{array}{l}\text { Exclusion of other causes of } \\
\text { hyprcapnia }\end{array}$} & $\begin{array}{l}\text { Non-obstructive sleep hypoventilation (apnea-hypopnea index }<5 \text { events/h) in } 10 \% \text { of cases } \\
\text { Severe obstructive airways disease }\end{array}$ \\
\hline & Severe interstitial lung disease \\
\hline & Severe chest-wall disorders (eg. kyphoscoliosis) \\
\hline & Severe hypothyroidism \\
\hline & Neuromuscular disease \\
\hline & Congenital central hypoventilation syndrome \\
\hline
\end{tabular}


lain dapat memiliki kelainan restriksi sedang atau berat dan desaturasi oksigen nokturnal dengan Nilai AHI yang rendah. Pasien-pasien ini akan memerlukan NIV atau BPAP jangka panjang. Bantuan kontrol terhadap tekanan diperlukan jika CPAP gagal dilakukan. ${ }^{27}$

Insiden OHS meningkat secara signifikan sebagaimana obesitas juga meningkat, dengan prevalensi yang dilaporkan sekitar 10 sampai $20 \%$ pada pasien rawat jalan yang datang ke klinik tidur. Hampir 50\% dari pasien rawat inap dengan BMI lebih besar dari $50 \mathrm{~kg} / \mathrm{m}^{2}$. Estimasi saat ini menunjukkan bahwa sekitar $0,15-0,4 \%$ dari populasi mungkin memiliki OHS. ${ }^{28}$

Obesitas, terutama bila sudah parah, dapat dikaitkan dengan perubahan-perubahan yang signifikan terhadap mekanika paru dan kinerja otot pernapasan. Pada tipe obesitas yang sederhana (ringan), ada juga data yang menunjukkan bahwa pengaruh mekanik relatif kurang penting, dengan perkiraan penurunan sebesar $0,5 \%$ pada VC, TLC, dan RV dimana setiap unit terdapat peningkatan BMI dan penurunan sekitar $1 \%$ di FRC dan ERV untuk setiap unit peningkatan BMI. Namun, hal ini memberikan pengaruh yang cukup besar pada pasien obesitas yang memiliki OHS dibandingkan dengan individu gemuk dengan atau tanpa sleep disordered breathing.

Obesitas, dengan distribusi lemak sentral yang luas, bertindak sebagai beban pada sistem pernapasan, yang berarti bahwa berat badan ditempatkan pada aparat pernapasan juga dapat meningkatkan inersia kerja otot pernapasan. Telah ditemukan bukti bahwa distribusi lemak dengan pola sentral dapat dijadikan sebagai prediksi dari gangguan fungsi paru yang lebih baik dari BMI. Hal ini menyebabkan penurunan yang signifikan pada kapasitas total paru, kapasitas vital, kapasitas residu fungsional, dan meningkatkan volume residual. Bernapas dengan volume paru rendah mengubah keseimbangan elastisitas antara dinding dada dan paru dan berhubungan dengan peningkatan resistensi paru dan kekuatan otot inspirasi. Compliance sistem pernapasan menunjukkan penuruan sekitar lebih sedikit dari $20 \%$ pada subyek obesitas eukapneu dibandingkan dengan individu dengan berat badan normal, dan hampir $60 \%$ lebih sedikit pada pasien dengan OHS. Bernapas pada volume ekspirasi rendah menandakan seperti bernapas dengan close volume, dan penutupannya kebanyakan bergantung pada jalan napas sehingga akan ada banyak udara yang terjebak mengakibatkan terbatasnya aliran ekspirasi, mikroatelektasis dan timbulnya suatu tekanan intrinsik positif akhir ekspirasi (PEEPi). Deposit lemak di dinding dada dapat memodifikasi mekanisme pernapasan dan mempengaruhi pertukaran gas, memburuknya ventilasi-perfusi terutama dalam posisi terlentang. Volume pernapasan yang rendah tidak hanya menimbulkan bernapas dengan kemampuan compliance yang minimal pada kurva volume terhadap tekanan dengan peningkatan usaha untuk mengatasi atau mengendalikan elastisitas sistem respirasi, tetapi juga terjadi keterbatasan pada volume tidal dan meningkatnya frekuensi bernapas dibandingkan dengan non-obesitas. Strategi ini diperkirakan dapat mengoptimalkan penggunaan oksigen, tetapi juga meningkatkan dead space. ${ }^{8}$

Subyek obesitas mengalami peningkatan jumlah konsumsi oksigen (VO2) dan produksi karbon dioksida (VCO2), bahkan pada saat beristirahat. Dengan demikian, orang-orang yang obesitas harus meningkatkan ventilasi semenit untuk memenuhi kebutuhan oksigen yang meningkat dan mempertahankan ventilasi alveolar agar tetap adekuat. Sentral pernapasan secara signifikan lebih tinggi pada eukapnik dengan obesitas dibandingkan individu dengan berat badan normal. Pasien OHS gagal untuk memberitahu sentral pernapasan untuk mengkompensasi beban tambahan yang timbul karena kelebihan berat badan, kondisi ini memungkinkan kenaikan bertahap CO2 terus berlangsung. Sentral pernapasan yang mengatur hiperkapnia dan hipoksia tumpul pada pasien OHS dibandingkan dengan subyek berat badan normal dan pasien obesitas eucapnic dengan atau tanpa OSA. Pasien dengan OHS dapat mencapai eukapnia selama hiperventilasi pada kondisi sadar, menyiratkan bahwa gangguan pada mekanika sistem pernapasan saja tidak menjelaskan terjadinya hipoventilasi. Pada obesitas sederhana, tekanan oklusi mulut juga lebih tinggi dibandingkan pada pasien tidak obesitas, tetapi belum jelas jelas apakah ini ditemukan juga pada penderita OHS. Dimana slope respons ventilasi hiperkapnia adalah < 11 / min / mmHg pada OHS, pada obesitas eukapnik antara 1,5 dan 2,5 $1 / \mathrm{min} / \mathrm{mmHg}$ dan pada subjek sehat 2-3 $1 / \mathrm{min} / \mathrm{mmHg}$. Penurunan respons ventilasi terjadi pada ketidakmampuan meningkatkan volume tidal sehingga menumpulkan respons persarafan dan menimbulkan hiperkapnia, hal ini ditunjukkan dengan adanya perbaikan pada pemakaian CPAP dan BPAP, atau tidak keduanya. Responss ventilasi hipoksia juga buntu pada penderita OHS. Ketidaknormalan ini tidaklah bersifat keturunan, dan dapat membaik bila diterapi dengan tepat. ${ }^{8}$

Perubahan pada respons ventilasi tidak homogen dan terkait dengan kewaspadaan siang hari. Individu dengan Hipercapnic Ventilatory Respons (HCVR) yang rendah sering mangalami kantuk di siang hari, secara langsung berhubungan dengan persentase yang lebih tinggi menghabiskan ventilasi tidur pada fase REM. Kurangnya hubungan antara BMI, HCVR, bikarbonat plasma dan $\mathrm{PaCO} 2$ yang mungkin menunjukkan di sisi lain bahwa obesitas dapat bertindak sebagai pemicu terhadap hipoventilasi pada pasien yang sudah memiliki kelainan fisiologis. Kelainan pertukaran gas awalnya akan terbatas fase REM, tapi seiring waktu sistem Buffer terjadi peningkatan karbon dioksida menekan Respiratory Drive yang akan mengurangi ventilasi tidak hanya selama tidur tapi selama terjaga. ${ }^{29}$

Sebuah komponen menarik dalam patogenesis OHS yang terkait metabolik obesitas dan efeknya pada kontrol ventilasi. Leptin adalah protein yang diproduksi khusus oleh jaringan adiposa dan berperan di pusat pernapasan untuk merangsang ventilasi, sedangkan defisiensi leptin dikaitkan dengan hipoventilasi. Telah dihipotesiskan bahwa kadar leptin yang tinggi dapat menjadi mekanisme kompensasi 
Tabel 3. Karakterisktik fungsi paru antara dengan hipoventilasi dan obesitas tanpa hipoventilasi ${ }^{8}$

\begin{tabular}{lcc}
\hline & Normocapnic morbid obesity & Obesity Hipoventilation Syndrome \\
\hline Lung Volumes: & & $\downarrow$ \\
FRC & $\downarrow$ & $\downarrow \downarrow$ \\
ERV & $\downarrow$ & normal or $\downarrow$ \\
TLC & normal & $\downarrow \downarrow$ \\
Respiratory Compliance & $\downarrow$ & $\uparrow \uparrow \uparrow$ \\
Respiratory Impedance & $\uparrow \uparrow$ & $\uparrow$ or $\uparrow \uparrow$ \\
PaCO2 (awake) & Normal & $\downarrow$ or $\downarrow \downarrow$ \\
PaO2 (awake) & Normal or $\downarrow$ & $\uparrow$ or $\uparrow \uparrow$ \\
HCO3- & Normal & normal \\
Repiratory Drive & $\uparrow \uparrow$ & $\downarrow \downarrow$ \\
HVR & Normal to $\uparrow$ & $\downarrow \downarrow$ \\
HCVR & Normal to $\uparrow$ & $\downarrow$ \\
MVV & $\downarrow$ & $\downarrow \downarrow$ \\
Pimax & Normal or $\downarrow$ & $\downarrow$ or $\downarrow \downarrow$ \\
Work of breathing & Sitting - Normal to $\uparrow$ & Sitting - $\uparrow \uparrow$ \\
& Supine $-\uparrow \uparrow$ & Supine $-\uparrow \uparrow \uparrow$ \\
& Sleep - sitting - $\uparrow \uparrow$ & \\
Upper airway resistance & Supine $-\uparrow \uparrow$ & Sitting $-\uparrow$ \\
& Sitting - Normal & Supine - $\uparrow \uparrow \uparrow$
\end{tabular}

Keterangan: HVR: hypoxic ventilatory respons, HCVR: hypercapnic ventilator respons

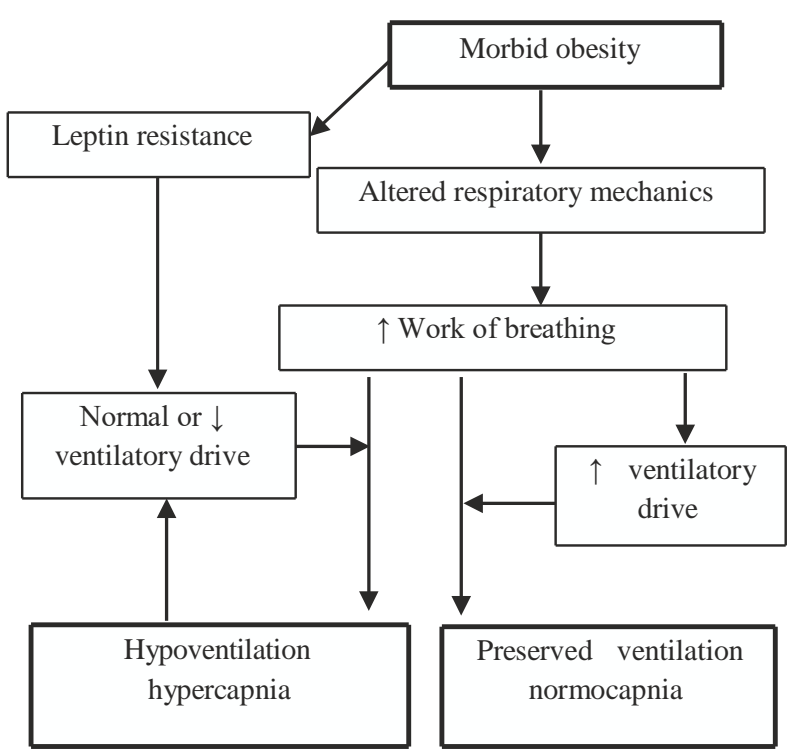

Gambar 2. Interaksi antara obesitas dan terjadinya hipoventilasi. ${ }^{8}$

pada subyek obesitas supaya tetap normokapnik, tapi resistensi terhadap leptin dapat terjadi. Mekanisme yang mungkin terjadi adalah resistensi leptin di sentral dan menurunya penetrasi leptin di cairan serebrospinal. Leptin mempengaruhi pusat pernafasan dan meningkatkan ventilasi semenit dan harus menembus barier darah-otak. Juga perubahan pada tingkat reseptor di sentral dapat dihipotesiskan. Pada beberapa pasien obesitas, resistensi leptin pusat dapat menyebabkan menekan pusat ventilasi demikian juga pada OHS. Telah dilaporkan bahwa konsentrasi leptin serum yang meningkat berhubungan dengan menurunya drive respirasi dan menurunnya respons terhadap hiperkapnia. Yang mencolok adalah kadar leptin merupakan prediktor yang lebih baik pada hiperkapnia dari pada derajat adiposit. Ventilasi non invasif reguler yang digunakan dapat menurunkan kadar leptin pada OHS, namun ini masih kontroversi. ${ }^{30}$

Telah disebutkan diatas perubahan sistem kontrol respirasi pada penderita OHS menyebabkan lebih berisiko tinggi terjadinya penurunan akut sistem ventilasi terutama disertai dengan kejadian yang baru seperti infeksi paru atau perburukan ringan pada fungsi jantung. Hal ini membuat penderita OHS lebih rentan terkena gagal napas. Secara bersamaan peranan mekanisme kontrol respirasi dan metabolisme leptin yang menurun menjadi suatu hal yang sangat penting. Kondisi ini menyebabkan ketidakmampuan untuk meningkatkan sentral pernapasan, terjadi penumpukan $\mathrm{CO} 2$, kemoreseptor menjadi tidak aktif dan pada akhirnya menimbulkan retensi $\mathrm{CO} 2$ di siang hari. ${ }^{31}$

\section{KESIMPULAN}

Peningkatan BMI biasanya berhubungan dengan penurunan volume ekspirasi paksa dalam satu detik (FEV1), kapasitas vital paksa (FVC), kapasitas total paru, Kapasitas residu fungsional dan volume cadangan ekspirasi.

OSA adalah keadaan terjadinya obstruksi jalan napas atas secara periodik selama tidur yang menyebabkan napas berhenti secara intermiten, baik komplit (apnea) atau parsial (hipopnea). OHS umumnya didefinisikan sebagai kombinasi antara obesitas (BMI $\geq 30 \mathrm{~kg} / \mathrm{mc}$ ) dengan 


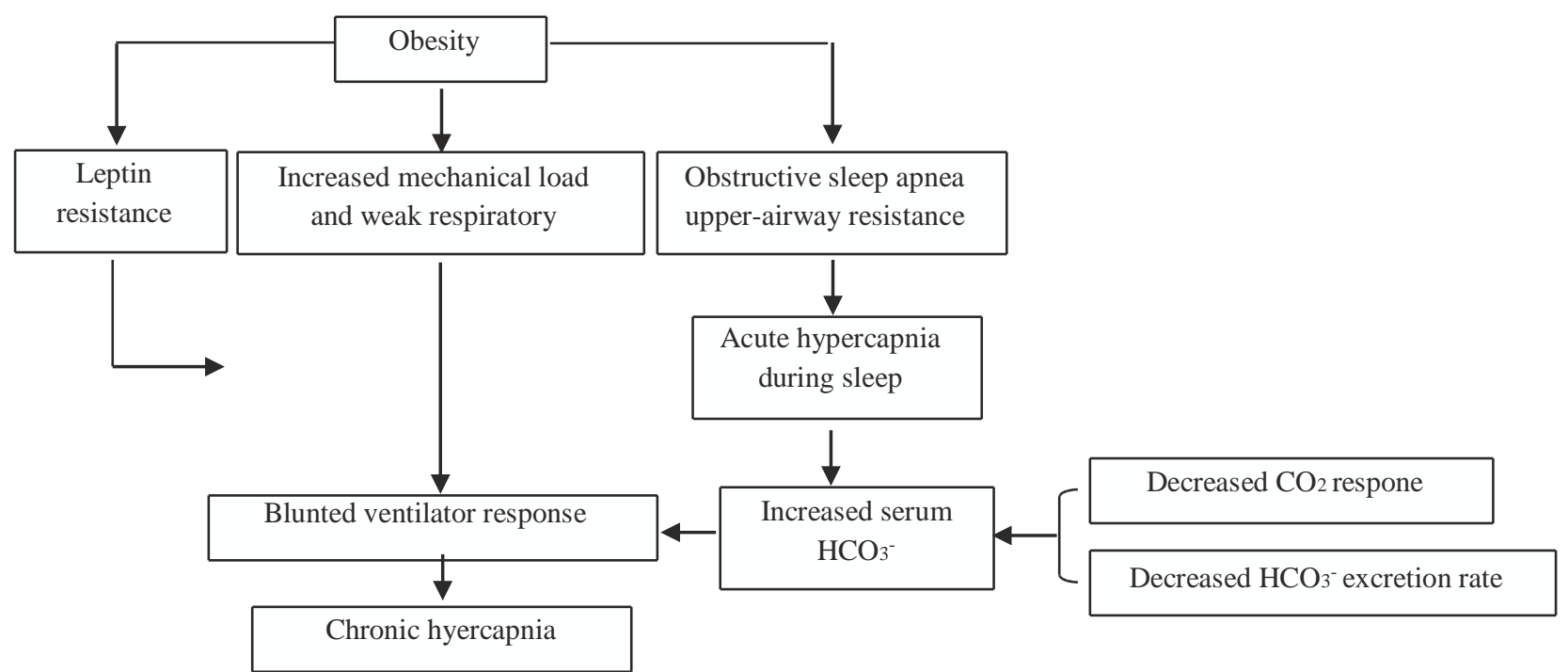

Gambar 3. Mekanisme obesitas menyebabkan hiperkapnia kronik di siang hari. ${ }^{9}$

hiperkapnia arteri saat terjaga $(\mathrm{PaCO} 2>45 \mathrm{mmHg})$ tanpa adanya penyebab hipoventilasi lain.

Leptin mempengaruhi pusat pernafasan dan meningkatkan ventilasi menit dengan menembus barier darah-otak. Resistensi leptin sentral dapat menyebabkan depresi pusat ventilasi dan terjadinya OHS dan kadar leptin merupakan prediktor yang lebih baik pada hiperkapnia.

\section{DAFTAR PUSTAKA}

1. International obesity taskforce (IOTF). Available: www.iotf.org/ indes.asp (accessed 15 November 2014)

2. Mokhdad AH, Marks JS, Storup DF, et al: Actual causes of death in the United States, 2000. JAMA; 291: 1238-45. 2004.

3. Conway B, Rene A: Obesity as a disease: no lightweight matter. Obes Rev; 5; 145-51. 2004.

4. Poulain Magali, Marieve Doucet, Geneieve C, dkk: The effect of obesity on chronic respiratory disease: pathphysiology and theurapeutic strategies. CMAJ; 174 (9): 1293-9. 2006.

5. Gordon Larsen P, Adair LS, Nelson MC, Popkin BM: five year obesity incidence in the transition period between adolescence and adulthood: the National longitudinal study adolescent health. Am J Clin Nutr; 80: 569-575.2004.

6. Zamarron C, Garcia Paz V, Morete E, del campo MF: Association of chronic obstructive pulmonary disease and obstructive sleep apnea consequences. Int J COPD; 3 (4): 671-682. 2008.

7. Borel JC, Borel AL, Monneret D, Tamisier R, Levy P, Pepin JL: Obesity hipoventilation syndrome: from sleep disordered breathing to systemic comorbidities and the need to offer combined treatment strategies. Respirology; 17: 601-610. 2012.

8. J Verbraecken, Mc Nicholas T Walter: Respiratory mechanics and ventilatory control in overlap syndrome and obesity hypoventilation. Respiratory Research; 14: 132. 2013.

9. Mokhlesi Babak: Obesity Hypoventilation Syndrome: A State-ofthe-Art Review. Respiratory care; VOL 55 NO 10. 2010.

10. Clinical guidelines on the identification, evaluation, and treatment of overweight and obesity in adults - The Evidence Report. National Institutes of Healt. Obes Res; 6 (Suppl 2): 51S-209S 1998.

11. Canoy D, Luben R, Welch A, et al: Abdominal obesity and respiratory function in men and women in the EPIC-Norfolk Study, United Kingdom. Am J Epidemiol;159:1140-9.2004.
12. Norman AC, Drinkard B, McDuffie JR, et al: Influence of excess adiposity on exercise fitness and performance in overweight children and adolescents. Pediatrics; 115: e690-6. 2005.

13. Sin DD, Jones RL, Man SF: Obesity is a risk factor for dyspnea but not for airflow obstruction. Arch Intern Med 2002; 162: 1477-81.

14. Arter JL, Chi DS, Girish M, Fitzgerald SM, Guha B, Krishnaswamy G: Obstructive sleep apnea, inflamation and cardiopulmonary disease. Frontiers in Bioscience; 9: 2892-900. 2004.

15. Svatikova A, Wolk R, Gami AS: Interactions between obstructive sleep apnea and the metabolic syndrome. Curr Diab Rep; 5: 53-6. 2005.

16. Bambang Supriyatno, Rusmala Deviani: Obstructive sleep apnea syndrome pada Anak. Sari Pediatri, Vol. 7, No. 2: 77 - 84. September 2005

17. Madani M: Snoring and obstructive sleep spnea. Arch of Iranian Med; 10 (2): 215-26. 2007.

18. Young T, Peppard PE, Gottlieb DJ: Epidemiology of obstructive sleep apnea: a population health perspective. Am J Respir Crit Care Med.; 165: 1217-39. 2002.

19. Somers VK, White DP, Amin R, Abraham WT, Costa F, Culebras A, et al: Sleep apnea and cardiovascular disease: an American Heart Association/american College Of Cardiology Foundation Scientific Statement from the American Heart Association Council for High Blood Pressure Research Professional Education Committee, Council on Clinical Cardiology, Stroke Council, and Council on Cardiovascular Nursing. In collaboration with the National Heart, Lung, and Blood Institute National Center on Sleep Disorders Research (National Institutes of Health). Circulation; 118: 1080-111. 2008.

20. Buxbaum SG, Elston RC, Tishler PV, Redline S: Genetics of the apnea hypopnea index in Caucasians and African Americans: I. Segregation analysis. Genet Epidemiol; 22: 243-53. 2002.

21. Cahyono Arie, Hermani Bambang, Mangunkusumo Endang, Perdana Riski Satria: Hubungan obstructive sleep apnea dengan penyakit sistem kardiovaskuler. ORLI Vol. 41 No. 1. 2011.

22. McNicholas WT, Bonsignore MR: Sleep apnea as an independent risk factor for cardiovascular disease: current evidence, basic mechanisms and research priorities. Eur Respir J. 2007; 29: 156-78.

23. Kryger MH, Roth T, Dement WC: Principles and practice in sleep medicine. $4^{\text {th }}$ ed. Philadelphia: Saunders, 2005. P. 765-8.

24. Iber C, Ancoli-Israel S, Chesson JrAL, Quan SF: The AASM Manual for the scoring of sleep and associated events: Rules, teminology and technical specifications. American Academy of Sleep Medicine, IL; USA; 2007 
25. Littner MR: Portable monitoring in the diagnosis of the obstructive sleep apnea syndrome. Semin Respir Crit Care Med 2005; 26 : 56-62.

26. Hillman David, Singh Bhajan, Mcardel Nigel, Eastwood peter: Relationships between ventilatory impairment, sleep hypoventilation and type 2 respiratory failure. Asian pasific Society of Respirology. Respirology; 10.1111/resp.12376. 2014.

27. De Liano Perez LA, Golpe R, Piquer MO, Racamonde AV, Caruncho MV, Lopez MJ, Farinas MC: Clinical heterogenity among patients with obesity hypoventilation Syndrome: theurapeutic implications. Respiration; 75: 34-39. 2008.

28. Kaw R, Hernandez AV, Walker E, Aboussouan L, Mokhlesi B: Determinants of hypercapnia in obese patients suspected of having sleep disordered breathing. J Clin Sleep Med; 9 (9): 879-884.
29. Piper Aj, Grunstein RR: Obesity hypoventilation Syndrom. Mechanism and management. Am J Respir Crit Care Med. 183: 292-298. 2011

30. Redolfi S, Corda L, la Piana G, Spandrio S, Prometti P, Tantucci C: Long term non invasive ventilation increases chemosensitivity and Leptin in obesity hypoventilation syndrome. Respir Med. 101: 1191-1195. 2007.

31. Hanaoko M, Yu X, Urushihata K, Ota M, Fujimoto K, Kubo K: Leptin and leptin receptor gene polymorphism in obstructive sleep apnea syndrome. Chest; 133 (1): 79-85. 2008. 